\title{
"TRUE HEIRS TO A HEROIC RUSSIAN PAST" OR "RUSSIANS IN NAME ONLY": SITKA CREOLES AS SEEN BY THE LATE NINETEENTH CENTURY RUSSIAN ORTHODOX CLERGY
}

\author{
Sergei Kan (a) \\ (a) Dartmouth College. Hanover, USA. Email: sergei.a.kan[at]dartmouth.edu
}

\begin{abstract}
The paper examines the criticism levelled against the Creoles of Sitka (persons of Russian and Alaska Native descent) by the Russian Orthodox priests who came to minister among them in the late 19th-early 20th century. These clergymen accused their parishioners not only of immorality but also of not being truly Russian, as far as their language and culture were concerned. By focusing on this criticism, the paper explores the symbolic significance of Alaska's Russian colonial and missionary history and its legacy in the conservative nationalist ideology of the Russian Orthodox clergy. Particular attention is paid to the causes to which this clergy attributed the decline of the Russian culture and devotion to Orthodoxy among the Creole population of this frontier American/Alaskan town.
\end{abstract}

\section{Keywords}

Russian Orthodox missionaries; conservative Russian nationalism; American Alaska (late 19th - early 20th centuries); Creoles; assimilation

This work is licensed under a Creative Commons «Attribution» 4.0 International License 


\title{
«ИСТИННЫЕ НАСЛЕДНИКИ ГЕРОИЧЕСКОГО РУССКОГО ПРОШЛОГО», ИЛИ «РУССКИЕ ТОЛЬКО ПО ИМЕНИ»: КРЕОЛЫ СИТКИ ГЛАЗАМИ РОССИЙСКОГО ПРАВОСЛАВНОГО ДУХОВЕНСТВА В КОНЦЕ ХІХ ВЕКА
}

\author{
Кан Сергей (a) \\ (a) Колледж Дартмут. Хановер, США. Email: sergei.a.kan[at]dartmouth.edu
}

\section{Аннотация}

В статье рассматривается критика, высказанная в адрес креолов Ситки (лиц смешанного русского и коренного происхождения) со стороны русских православных священников, прибывших служить в их среде в конце XIX - начале XX века. Эти священнослужители обвиняли своих прихожан не только в безнравственности, но и в том, что они не являются истинно русскими в том, что касается языка и культуры. Сосредоточившись на этой критике, статья исследует символическое значение русской колониальной и миссионерской истории Аляски и ее наследие в консервативной националистической идеологии русского православного духовенства. Особое внимание уделяется причинам, с которыми это духовенство связывает упадок русской культуры и православия среди креольского населения этого приграничного американо-аляскинского города.

\section{Ключевые слова}

Православные миссионеры; консервативный русский национализм; Американская Аляска (конец XIX - начало XX вв.); креолы; ассимиляция

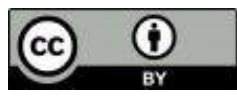

Это произведение доступно по лицензии Creative Commons «Attribution» («Атрибуция») 4.0 Всемирная 


\section{INTRODUCTION}

With the sale of Alaska to the United States in 1867, Russia lost its only overseas colony. The one Russian institution allowed to retain its property in Alaska and continue its activity was the Orthodox Church ${ }^{1}$. The conditions under which it now had to labor were characterized by continuity with the pre-1867 era as well as major changes. On the one hand, the Alaska churches continued to subordinate themselves administratively to the Mother Church in Russia and receive much of their financial support and key clerical staff from it. On the other hand, the Church was now operating in a foreign country without the backing and coercive power of the Russian-American Company (RAC). This regime change also meant that, with the RAC employees' departure, only a handful of ethnic Russians remained under its tutelage, while the majority of its faithful were now Alaska Natives and persons of mixed Russian and Native ancestry, whom the Russians referred to as "Creoles." Moreover, unlike Russia, where the state identified with the Orthodox Church and supported its activities, the American authorities not only were not Orthodox but had an ambivalent attitude towards the "old-fashioned" Church and the entire Russian colonial era of the newly acquired territory's history. On the one hand, they emphasized how little the Russians had done for the cause of developing Alaska's natural resources and civilizing its "savage" inhabitants. On the other, some of the American newcomers (at least the better educated ones) found Alaska's pre-1867 colonial history quite interesting and Orthodox churches quaint and intriguing, and by the 1880 s began using a heavily "edited" version of Alaska's Russian legacy to promote the new territory and market it - especially Sitka, the Russian America's former capital and the capital of the territory of Alaska until 1912 as well as the spiritual and historical center of the Orthodox Alaska mission and diocese - as a tourist destination.

As far as the Americans' views of the Orthodox Church members themselves, they ranged from contempt for most of the Natives to a willingness to accept a few of the "better" Russian-speaking families as "White." The racially mixed Creoles were viewed through the lens of the late-nineteenth century American racial ideology as a "degenerate mixedbreed" population. In Sitka, the focus of this paper, this negative view was further supported by the fact that, in the first few decades after 1867, many of the Creoles found themselves on the bottom of the socioeconomic ladder.

\footnotetext{
${ }^{1}$ The history of the Russian Orthodox Church in Alaska is discussed in several publications authored by Orthodox clergy. See Afonsky (1977); Oleksa (1998); Metropolitan Clement (2009). For ethnohistorical studies of the Orthodox missionary work among the Alaska Natives see Znamenski (1999); Kan (1999).
} 
Thus, the challenge faced by the Russian clergy in Sitka was not only to keep their gradually Americanized Russian-Creole parishioners within the Orthodox fold but to present them to the local non-Orthodox establishment in a positive light, so as not to embarrass Mother Russia and its Church.

By focusing on the criticism the Russian-born Sitka priests directed at many of their parishioners in the 1880s-1900s as well as the praise they reserved for a selected few, this paper explores the symbolic significance of Alaska's Russian colonial and missionary history and its legacy in the conservative nationalist ideology of the Russian Orthodox clergy in the last quarter of the 19th century-beginning of the $20^{\text {th }}$ century. I am particularly interested in the causes to which this clergy attributed the decline of the Russian culture and of devotion to Orthodoxy among Sitka's Creole population.

\section{SITKA CREOLES SOCIETY BEFORE AND AFTER $1867^{1}$}

In 1867 on the eve of sale of Alaska to the United States, the population of Novoarkhangel'sk (Sitka) consisted of about 500 persons who had been born in Russia (and whom the church records listed according to their soslovie and/or occupation) (St. Michael Cathedral, n.d.), some 60 Aleuts $^{2}$, 35 Tlingit mainly from the village next door, and 380 Creoles. The fact that the Church counted separately all those who were the offspring of Russian or Creole fathers and Native or Creole mothers was not a sign that it was thinking primarily in terms of ethnic or racial categorization. Legally codified in the early $1820 \mathrm{~s}$, the Creoles constituted a hereditary social estate made equal to that of meshchane (urban dwellers) in Russia. They were educated at the Company's expense but in return were obligated to serve it as navigators, trading post managers, priests, etc. This was a unique colonial creation, which solved the problem of labor shortage, kept Company workers from leaving Alaska, and produced a naturally growing colonial population with loyalties to the Russian colonizers and kinship connections to the indigenous people. Although the Company's Russian-born employees (particularly those of the upper echelons) looked down on the Creoles, their attitudes were influenced as much by the estate-based as by the racebased prejudices. In fact, the rhetoric of race was definitely less pro-

\footnotetext{
${ }^{1}$ On the Creole estate in Russian America see Ilya Vinkovetsky (2011), Andrei V. Grinev (2011), Susan Smith-Peter (2010; 2013). On Creoles in the post-1867 era see Sergei Kan (2013a).

${ }^{2}$ Parish Records Confessional Lists for 1867, St. Michael Cathedral, Alaska Russian Church Archives, Library of Congress, D 414, Reel 265. This Alaska Russian Church Archives [ARCA] is the main archival source used in this paper. The term "Aleuts" was used by the Russian Orthodox clergy to refer to the Aleut (Unangan) people proper as well as the Alutiiq (Sugpiaq) people from Kodiak Island and the coastal areas adjacent to it.
} 
nounced during the Russian colonial era than after 1867 when Alaska became American (Luehrmann, 2008, pp. 113-153) .

The 1867 treaty between Russia and the United States stated that, "The inhabitants of the territory, according to their choice ... may return to Russia within three years; but if they should prefer to remain in the ceded territory, they, with the exception of the uncivilized native tribes, shall be admitted to the enjoyment of all the rights, advantages, and immunities of citizens of the United States" (A Century of Lawmaking for a New Nation: U.S. Congressional Documents and Debates, 1774-1875, n.d.). Wishing to return to the mother country and seeing no future for them, now that the RAC's operation in Alaska had ended, most of the Russians chose to leave Sitka between 1867 and 1869. A few, who had either been away from Russia for too long or were more entrepreneurial than others, did take advantage of the citizenship offer. A number of Creoles also left Sitka, but the majority stayed behind, some because of their attachment to relatives and places in Alaska, and many because of poverty and general confusion. In the first decade following the transfer, only a few of the Creoles took advantage of American citizenship: unable to speak English (or speaking a rudimentary version of it) and perceived by the Americans as being more Native than white, they now had a very ambiguous social status, much lower than the one they had enjoyed under a paternalistic Russian rule. Many of the Russians/Creoles remaining in Sitka were those who had occupied the lower ranks of the RAC's social hierarchy (Grinev, 2011).

During this time many of the Creole men were unemployed, surviving by occasional odd jobs, US Army relief, and petty crime. Some of the Creole women worked as laundresses, servants, and nannies for the local society's upper crust. The majority, however, had no sources of income at all. Given a large number of widows and single women with no relatives to support them, it is not surprising that prostitution was listed as the occupation of thirty-five Creole women in the 1870 US Army census of Sitka ${ }^{2}$. Since most of the Americans who descended on the town in the late 1860s were single men, demand for women was high, with the Russian/Creole females seen as more attractive and culturally a bit more proximate to the

\footnotetext{
${ }^{1}$ The influence of racialist ideas on the pre-1867 Russian observers of Alaska Natives and Creoles requires further research. I agree with Ilya Vinkovetsky that race did matter for the visiting Imperial Navy officers who viewed the Creoles in a negative light, emphasizing the detrimental effect of their Native mother's blood and its mixing with Russian blood (Vinkovetsky, 2011). Even the enlightened Bishop Ioann Veniaminov's (St. Innocent) critical characterization of the Russian-Aleut Creoles' echoed some of these views. See Ioann Veniaminoff (1984, pp. 166-188).

${ }^{2}$ Sitka Orthodox church records for the 1870 s contained a separate category of a dozen Creole women (some with children) listed as "left behind and separated" from their husbands (Parish RecordsConfessional List, ARCA, 1870). For the US Army 1870 census of Sitka see Cracroft, S., \& DeArmond, R. N. (1981, pp. 93-125).
} 
whites than the local Tlingit ones ${ }^{1}$. With a sudden influx of poorly disciplined American soldiers and frontier riffraff, drinking, selling liquor to the Tlingit, debauchery, theft, and physical violence became quite common and often involved the so-called "Russians". The demoralization of many of the Creoles was also reflected in their poor church attendance and the decline in the number of children being sent to the parish school ${ }^{2}$.

While there were clearly some objective reasons for the poverty and social disorder that struck the "Russians" in the late1860s-early 1870s, they suffered just as much from prejudice that characterized the American perception of their community. Since most of them could not speak English and especially given the low status of "half-breeds" or "mixed-bloods" on the post-Civil War American frontier, it is not surprising that the Creoles suddenly found themselves in a marginal position, being assigned to a rank only slightly above the "uncivilized tribes" (i.e., Alaska Natives) (Lain, 1976, p. 148). It did not help that they shared their church with Alaskan Natives, including a group of recently converted, (mostly) local Tlingit Indians whom the Americans still mistrusted and feared, and that some Creoles even served as the godparents to them. To the Yankees, who expected to find a "wild" land inhabited only by "savages", these racially and culturally mixed people posed a serious challenge because they undermined prevailing assumptions about the existence of naturally separate races. Unable to determine who among the Sitka "Russians"/Creoles was truly "white" and thus qualified to be citizens, government officials had to resort to various criteria besides their physical characteristics, such as income, education, moral character, and the degree of social separation from the neighboring Native (Tlingit) community.

Some of the Russian and Creole men and their families, especially those who managed to find a niche in the new political and economic structure of the town and/or could claim "respectable status" in the old RAC hierarchy, were considered "white" by the Americans, granted citizenship and even invited to sign the first city charter (Lain op. cit.) ${ }^{3}$. A dozen Cre-

\footnotetext{
${ }^{1}$ Until about 1880 most Tlingit people were kept out of the town at least during the night hours.

${ }^{2}$ Education - school records journal (ARCA, n.d. - b). The fact that during the first decade of the US rule, most Americans in Sitka rarely went to church also had to have an effect on the Creoles' lack of diligence in fulfilling their religious duties.

${ }^{3}$ The question of citizenship is a complex one. Thus the 1871 Confessional Records of the St. Michael's Cathedral (ARCA, n.d. - c) lists seventy-seven Orthodox parishioners as "American Citizens", while the rest of the parish, numbering 223, is classified under such headings as "members of the clergy estate", "Creoles", "Creole widows", "Aleuts" and "Kolosh [Tlingit]". It is not clear from the records whether all of the sixty-five men and forty-four women listed as "American citizens" had actually been granted American citizenship or whether the priest, who had filled out the form, had simply assumed that. What is clear, however, is that some of these "US citizens" (e.g., the Kashevaroffs) were Creoles. Hence the fact that some families had been granted American citizenship and others had not, had less to do with their biological ancestry than with their social and economic status within the American-dominated Sitka.
} 
ole women raised their status by marrying American men of a "better class" who operated various businesses in town or at least engaged in trades that brought them a steady income. The majority of the "Russians", however, were characterized by the Americans as "superstitious, filthy, drink-addicted, lazy, stupid, immoral, and generally unfit for United States citizenship." (Lain, op. cit.). US Navy Commander Beardslee, who arrived in Sitka in 1879, stated that he found "very few respectable people" in town and "a large number of Russians and half-breeds, miserable povertystricken creatures, whom it would not be worthwhile to take much trouble about, were it not for our pledge to Russia." (Lain op. cit.). This prejudiced view of the Sitka Creoles persisted for several decades, even though by the late 1800s quite a few of them had found some legitimate sources of income and were becoming more integrated into the town's economy and society. Thus, a Sitka weekly stated in 1891 that "....after Alaska became part of the Union, most of the Russians went back to the mother country, the Bishop migrated to San Francisco, leaving only three real Muscovites in the diocese. The rest of the congregation is made up of Creoles, Indians, and half-breeds, the latter exhibiting the vices that generally come of mingling the blood of degenerate races" (The Alaskan, 1891). It should be pointed out that the local Americans were inconsistent in their attitudes: they were more likely to describe their individual "Russian" neighbors in more respectful terms but attach denigrating labels to the "Russian-CreoleOrthodox" community as a whole. Ethnic and racial stereotyping was also more likely to come to the fore whenever occasional disputes over property and other issues related to wealth and power between the two communities arose.

Particularly hurtful to the Russian/Creole pride was the fact that most of the Americans looking down upon them were themselves considered to be on the very bottom of Sitka's social hierarchy. Thus Emil Teichmann, a British citizen, who visited Sitka in 1868, pointed out that while the Army officers' conduct in the late 1860s was bad enough, that of the rank and file was simply atrocious. In his own words, "the few respectable people in town were more on their guard against the soldiers than against the Russians, who were at least good-natured, or even the treacherous Indians" (Teichmann, 1963, p. 88). In addition to being poorly disciplined, General Davis' troops were simply bored, because the anticipated "Indian threat" never materialized. To pass the time they drank, socialized, and cohabited with Sitka's "lower class" inhabitants, many of them "Russian half-breeds" whom the soldiers themselves saw as inferior. During that early American era, Sitka's American elite as well as its "middle class" were fairly small; 
moreover, for several decades after 1867 the Russians/Creoles outnumbered the Americans within the town's population ${ }^{1}$.

\section{CREOLE/RUSSIAN CULTURE IN SITKA}

Despite their economic, social and moral decline, the Sitka Creoles persisted as a distinct community for at least fifty years. In the first decades after the sale of Alaska they constituted a separate and substantial segment of Sitka's population, which the rest of the town's inhabitants could not ignore. Many of Creoles were related to each other and lived in a compact neighborhood widely referred to as the "Russian town". The majority among them shared a common language and a common historical memory of Russian America. While we do not know much about their daily life or "informal" culture, I believe it was rooted in Russian rural values, with some beliefs also derived from Aleut (Unangan) and Alutiiq (Sugpiaq) cultures, since the majority of the Sitka Creoles had Aleut (Unangan) and Alutiiq (Sugpiaq) ancestry. A kind of folk Orthodoxy, i.e., their own version of Orthodox belief and ritual system, was clearly central to this worldview and constituted a common denominator for both the better educated and more Russified members of the community as well as the ones who were illiterate and culturally closer to its Alaska Native members. Church holidays and the various culinary and festive traditions associated with them were part and parcel of this localized Alaska Russian/Creole culture.

Judging by the reminiscences of Sitka residents I collected (most of them Orthodox Tlingit) as well as the reports in the local American newspaper, Orthodox Christmas was the most popular Creole holiday (Kan, 1999, ch. 9) (Kan, n.d. - a). What the local Orthodox were especially fond of was the season of masked visitations and dances that followed the Russia Christmas (sviatki). In Sitka it involved the majority of the Creole community and lasted from January 7 till at least the 16th. This celebration was so popular in the Orthodox community that the local priest, Fr. Nikolai Mitropol'skii, who served in Sitka between 1875 and 1885 and was married to a Creole woman, gave his own masked ball for a large company of Creole guests (ARCA, n.d. - e). By this time, many of Sitka's non-Orthodox inhabitants, from the ordinary laborers and soldiers to the Navy officers and their wives, joined the fun. There were balls for the "high society" and "big hops" for the common folk. In fact, by the 1870s, the sviatki season seems to have become a major opportunity for what was locally referred as

\footnotetext{
${ }^{1}$ The Sitka Creoles' difficult condition is further illustrated by the fact that ten years after the sale of Alaska some of them were still petitioning the Russian government for financial assistance to help them relocate to Russia. These requests did not produce any results (ARCA, n.d. - e).
} 
"Russian" community not only to fraternize with the non-Russians but even play the role of the hosts and masters of ceremony. Visitations and feasts that followed the Easter Sunday were equally popular but were limited to the Orthodox Church members and their non-Orthodox spouses. Other church-related ceremonies that drew large numbers of Creoles (and eventually Tlingit as well) included a procession (krestnyi khod) around the town on Annunciation Day, involving the clergy blessing each Orthodox home (ARCA, n.d. - e).

It goes without saying, that many of these celebrations were accompanied by or ended in various degrees of alcohol consumption, some of it quite heavy. The local Americans' attitudes towards the "Russian disease" varied depending on their social class and degree of involvement with the Creole community. Russian clergy tried to combat such conduct, but under Fr. Mitropol'skii, who was fond of parties himself, fighting intemperance did not seem to be a major priority.

Things changed with the arrival of his successors, Fr. Vladimir Donskoi, Fr. Anatolii Kamenskii, and several others and it is their views on the Creoles that are the main subject of this paper.

\section{"WHAT'S RUSSIAN ABOUT THEM"?}

When analyzing the rhetoric, the Russian-born priests used to describe Sitka, one should keep in mind that they invariably viewed it as "Novoarkhangel'sk", the capital of the once glorious Russian colony, lost forever to a foreign power. As Bishop Nikolai wrote in his travel journal about his first impression upon arriving in Sitka in the early 1890s, "It saddened me to hear on this far-away frontier the sound of Russian canons being fired but not in honor of the Russian flag. Right where once the Russian tricolor once waved, now the star-spangled flag of the free states was waiving" (Ziorov, 1893, pp. 34-35). In the Russian clergymen's description of the pre-1867 residents of Novoarkhangel'sk, they were always characterized as the true Russian patriots who could not imagine themselves living under a foreign flag and for that reason departed from Alaska as soon as they could. In sharp contrast to them, those former employees of the RAC who decided to stay were depicted as somehow not truly Russian - ethnically and/or culturally. Fr. Anatolii Kamenskii, a strong Russian nationalist and monarchist (and a future activist of the right-wing and anti-Semitic Union of the Russian People) put this most bluntly, "When the Russian flag was lowered there [in Sitka] in 1867, the majority of the purely Russian population left. With very few exceptions, the people remaining in Sitka were Russian 
zhidy, adventurers, prostitutes, and poor Creoles" (Kamenskii, 1908, p. $13)^{1}$.

The priests' description of the town and its "glory days" were always marked by heavy nostalgia and idealization of the RAC's alleged benevolently paternalistic but just rule over its employees. In these nostalgic paeans, the latter were described as good Christians, obedient to the clergy and diligent in fulfilling their religious duties. According to them, once the Company's control over its population had been removed and the Church's hold on them weakened, the moral and spiritual life of Sitka's Russianspeaking community rapidly deteriorated. Here is another comment by Kamenskii, "Given the onset of lawlessness and a general civic disorder, the lowest passions, which had once been kept in check by strict colonial laws, surfaced. Something disgusting had begun, which can only be described as a wild bacchanalia" (Kamenskii, 1908, p. 13).

What were those aspects of the Creoles' life that the Russian clergy attacked most vigorously? Undoubtedly their addiction to heavy drinking and the accompanying troubles with the law caused by making homebrew, selling liquor to the Tlingit, fighting, prostitution, and so forth were high on the list of social problems that the Russian-born priests condemned. Remarkably the Orthodox clergy chose to ignore the fact that drinking by the RAC's Russian, Creole and Native employees had also been a major issue and that back home their own parishioners had hardly been teetotalers, but preferred to blame the problem on the influence of the lower-class American frontiersmen and soldiers who had overwhelmed Sitka during the first few years after 1867.

Through sermons and evening poucheniia (instructions) as well as with the help of a temperance society (first organized in 1885 mainly as a cultural and mutual aid society and revived in 1892 under the name of "The Brotherhood of St. Nicholas") the Orthodox clergy managed to make some progress in combating these vices. However, it seemed to have done better with the older generations of Creoles than with the younger ones who must have found the brotherhood activities and meetings less meaningful than their parents and grandparents did. In the 1880s-1890s Sitka was no longer a rough and tumble frontier society; this meant that the clergy had to explain the persistence of drinking and other vices among some of the younger Creoles. Drawing on their dualistic vision of the world, in which the "good Russian Orthodoxy/autocratic Russian" social order was juxtaposed to the "evil Protestant sectarian/(pseudo) democratic American" one, they blamed the problem on the influence of the unsavory local Americans who had (allegedly) replaced the Church as the major influence on the Creole

\footnotetext{
${ }^{1}$ It should be pointed out that there were no Jews in Novoarkhangel'sk during the Russian colonial era.
} 
youth. As Kamenskii wrote in one of his reports, "As far as the youth is concerned, with a few exceptions, these are spoiled young people who have forgotten the Church. They are also a stronger part of the community who are less in need of the others' help. Having been spending a lot of time since their childhood among shady newcomers (soldiers and sailors), in all sorts of saloons and bars, they get used from early on to drinking vodka, and to all sorts of debauchery and perversity" (Kamenskii, 1897c).

Actually, an improvement in the Creoles' socioeconomic status in the late19th century, rather than the priests' labors, seemed to have had had more to do with this moral progress ${ }^{1}$. Starting in the 1880 s, church records contain apologies from those Creoles who had steady jobs and were Orthodox Church and St. Nicholas Brotherhood members in good standing, for not being able to attend services and society meetings regularly because of the demands of their work. Reluctantly, the priests had to forgive them. Thus, a Church transplanted from a more traditional paternalistic society had to adjust to the schedule of a more advanced capitalist one.

As far as intemperance in Sitka was concerned, there was a great deal of it among the lower class of the Euro-American community as well, but when the Sitka "Russians" drank and partied, their behavior was duly noted by the rest of the population and attributed to a cultural tradition and even a racial one (i.e., the mixing of Russians with the "degenerate native races"). Moreover, the Orthodox Sitkans had a lot more Church-related holidays, during which to engage in such behavior, especially the January sviatki season, marked by what the clergy called "debauchery" [razvrat]. Ironically, when the Russian-born priests preached against these celebrations (especially masking as being pagan in origin and any partying on the eve of church holy days), the Creoles viewed their words as an attack on their own Russian culture, i.e., one of the few remaining authentic and unique cultural traditions that not only set them apart from the rest of the Sitkans but were being viewed with amusement and even partially appropriated by the latter as part of the town's special heritage. A more effective way to combat intemperance, which the clergy used, was to appeal to the Creoles' sense of national pride by telling them that they were embarrassing their identity as "Russians" vis-à-vis the local Americans.

If drinking was a vice Sitka Creoles shared with much of Russia's lower-class population and thus was familiar to their spiritual fathers, their

\footnotetext{
${ }^{1}$ As I have mentioned earlier, unemployment and underemployment were the worst afflictions that the Sitka Creole community suffered from in the first three decades after Alaska became American. This would explain why the most popular and successful aspect of the St. Nicholas Brotherhood's work was not the promotion of temperance among its members but mutual aid. Brotherhood members maintained a modest mutual assistance fund, which needy members could borrow money from, and also tried to provide help and care for sick and infirm members. See Kan (n.d. - b).
} 
other major "flaws" were seen by the priests as American in origin. To begin with, they could not accept the fact that some Orthodox parishioners, especially the younger ones, could no longer speak Russian (or at least fluent Russian), and quite a few were unable to read or write in the language of their mother country. To the nationalist Russian clergy, this loss of the Russian language and culture by their Russian-American flock was as tragic as its moral degradation. This situation also created a practical problem for the priests - none of them arrived in Alaska with any (reasonable) command of English and could only preach to their flock in Russian ${ }^{1}$.

Fr. Vladimir Donskoi, who came from Siberia in 1886, stayed in Sitka for ten years, and revitalized the work of the Church among both the Creoles and the Tlingit, referred to the local Creoles as "a miserable remnant of a Russian society that had once existed in Sitka" and as "people who are barely educated, ignorant, and crude" (ARCA, n.d. - d). Fr. Anatolii Kamenskii, who replaced Donskoi in 1895 and in the late 1890s promoted Russian education among the Creole youth even more vigorously than his predecessor, expressed this idea in harsher terms when he wrote that many of the local Creoles (including those women who engaged in sexual "debauchery") were shaming the very word "Russian" by their existence. "And what's 'Russian' about them?" continued Kamenskii, the stern moralist:

Only that he or she, while being drunk, would wander into the Church by mistake and would start speaking the worst bastardized and disgusting dialect of Russian and that's all. And then there is their lack of respect towards the Church, lack of fear of God, no idea of honor, noble behavior, moral and civic duties, or spirituality; there is also no sense of self-respect (and where would it come from, anyway). There is no attachment to and love for one's relatives. Everything that is good and kind has been totally twisted, broken up, and uprooted. How can any good influence be made on such ... creatures? It is easier for God to create new human beings than improve these ones (Kamenskii, 1897c).

To stem the decline of Russian language in this community, the clergy relied on the abovementioned brotherhood as well as the parish school. Thus, only those able to speak Russian could be the brotherhood members and its business was conducted in Russian. For the patriotic and nationalist priest of the late 19th century Orthodoxy had to be preached in Russian ${ }^{2}$.

\footnotetext{
${ }^{1}$ This contradicted the Orthodox tradition of preaching in the local vernacular languages. Only in later years, when the Alaska diocese began training and appointing some Alaska-born English-speaking clergy for Sitka, was this communication problem at least partially solved. When preaching to the Tlingit, the clergy had to rely on interpreters.

${ }^{2}$ Thus, one of the statutes of the St. Nicholas Brotherhood said the organization's purpose was "to encourage love of the Russian language used by the Church to teach the truth of the Orthodox Faith and to try to ensure that the children of the members learn this language" (ARCA, n.d. - i).
} 
The problem, of course, was not with the older generation of the Creoles but with their children and grandchildren who studied in English in the local American school (and especially those whose fathers were Englishspeaking men married to Creole women). Archival materials and local oral history indicate that while spoken Russian persisted in Sitka at least through the 1910s-1920s, the number of people capable of reading and writing it declined significantly already by the 1890s-1900s. The Creoles, especially those who wanted their children to succeed in the larger world, were not very eager to send them to the Orthodox parish school, while many of the children themselves interacted almost as much with the fellowCreoles as with non-Creoles. Without a continuous influx of immigrants from Russia, the Sitka Creole community was simply too small to reproduce itself biologically and culturally.

Nonetheless, for the first fifty years or so after the sale of Alaska, when the Orthodox Church maintained direct ties with the Mother Church in Russia, the Sitka parish continued to express its identity as a distinct Russian American community. On the one hand, some of this identity must have been genuinely experienced by many of the Creole parishioners (especially the older ones), who still did not feel fully accepted into the local American community and continued to identify with the RAC, its history, and its symbols ${ }^{1}$. On the other hand, the Orthodox clergy consistently promoted a celebration of various anniversaries of the key landmarks in the history of the Russian religious mission in Alaska as well as the major events in the life of the Russian imperial state. Thus, for example, in May 1896 Fr. Anatolii invited his parishioners to discuss how best to celebrate the upcoming coronation of tsar Nicholas II and encouraged them to send a special congratulatory message to the new emperor via the Russian ambassador. Fifteen years later, Alaska bishop Alexander (Nemolovskii) passionately appealed to the faithful in Sitka's cathedral not to listen to the criticism of Russia's domestic and foreign policies spread by American Russian-language newspapers owned by "all kinds of Swedes, run-away Finns, Poles, Kikes (zhidy) and other human refuse, some of it in Alaska, who make fun of Russia and of those few Russians living and working in Alaska" (Russian Orthodox American Messenger, 1911, pp. 301-302). While many in the bishop's audience must have thought of themselves as Russian patriots, I doubt that more than a handful remained true monarchists. Inevitably, as time went by, the Sitka Creoles were becoming increasingly Americanized and it was that process that the Russian clergy resented most.

\footnotetext{
${ }^{1}$ Among the popular projects initiated by the St. Nicholas Brotherhood and supported by much of the St. Michael's parish in the late 1800s, was the building of a marker on the graves of the Russian sailors killed in 1804 during the battle between the Russians and the Tlingit.
} 
Summing up his nine-year experience of laboring among the Sitka Creoles between 1886 and 1895, Fr. Donskoi wrote to another Sitka priest, "As far as their moral characteristics and spiritual state are concerned, the Creoles are worse than our Russian peasants and meshchane [urban dwellers]. They are freethinking, rather rude, impertinent, lacking in discipline and not easily influenced by the Church's moral teaching. I struggled with them for five years and only in the last few years, once their own brotherhood had been established, which brought me closer to them, was able to influence them" (ARCA, n.d. - g). The word "freethinking" is the key here. What the priest meant was that the Creoles no longer accepted everything the clergy told them at face value. In another passage from the same letter, he attributed this development to their having become American. In his words, "they have become American citizens, but having misunderstood the freedom proclaimed by the [U.S.] constitution, they have developed a liberal attitude even towards the advice and the teachings of the Holy Orthodoxy. One can often hear from a Creole, 'This is America - a land of freedom and here everyone is allowed to live as he wishes to"' (ARCA, n.d. - g). In Donskoi's view, this freedom meant that the Creoles still loved their Church but "in their own peculiar way": they violated the holy fasts often, did not attend services very often, did not work hard to maintain the church building, and so forth.

Fr. Anatolii echoed this sentiment when he insisted that his flock had been infected with an "American spirit" and thus resented his "Russian" (i.e., heavily paternalistic) style of running the parish. Hence his attempt to discipline unruly students was met with the parents' response, "This is not Russia where one can whip students" (Kamenskii, 1897a, p. 12). He was also frustrated by the St. Nicholas Brotherhood's repeated attempts to gain greater independence from the clergy by removing the local priest from serving as the society's overseer and allowing the members to spend the money from their treasury without consulting him or the bishop (e.g., on establishing a brotherhood's own grocery store). Thus, instead of heeding Kamenskii's pleas to strengthen the organization's efforts to promote "the propaganda of Russian language, Russian customs, and Russophilism in general" , it was trying to act more like an American fraternal organization $^{2}$. In Kamenskii's view, insubordination to the clergy could only come as a result of a pernicious influence of the American society.

\footnotetext{
${ }^{1}$ When Kamenskii suggested that the Brotherhood's revised statutes be published in Russian only, he was corrected by one of the organization's prominent lay members who pointed out that many brothers and sisters could no longer read Russian and hence needed to have them printed in the "American" language as well (ARCA, n.d. - h).

${ }^{2}$ This was not the first attempt by the Sitka Orthodox parish to gain some degree of independence from its clergy or at least to have some say in the way the parish was run. Thus in 1885-1886 a group of parish-
} 
Fr. Anatolii's main attack was directed at the American capitalism characterized by greed and individualism. His immediate successor, Fr. Antonii Dashkevich put it best, when he described his own job as bringing back together again as friends these "persecuted, abandoned Russian people, dying under the influence of a dry Americanism and utilitarianism, which devours and swallows everything [good]" (Dashkevich, 1898, p. 5). For the Russian clergymen, strong believers in an estate-based corporate state, this Yankee individualism inevitably led to excessive freedom and insubordination, which, in their view, would be particularly dangerous for poorly educated persons lacking moral and spiritual guidance. Hence, for Fr. Kamenskii and his Russian-born colleagues, many of the Creoles became Americanized in a wrong way or totally misunderstood what it meant to be American. Here is how he described this phenomenon: "American civilization, like any other, when dealing with such people, can only plant bad seeds in such a soil. In this case it only adds more pride and cockiness, expressed in such words as, 'I live now in the land of liberty [sloboda] and not the one of rods [rozgi] and can speak English,' although so badly" he added, "that Uncle Sam still has to keep an interpreter at the court" (Kamenskii, 1897a, p. 14). Kamenskii's ultimate verdict was simple: the majority of the Creoles were neither true Russians nor true Americans. They had drifted away from their Mother Church and their cultural heritage but did not become truly American either.

"Freethinking" also meant that some of the more Americanized Creoles were beginning to question the fundamental teachings of the Orthodox religion itself ${ }^{1}$. In this respect, the Russian priests in southeastern Alaska preferred to deal with the Tlingit who, despite being only the "newlyconverted from paganism", tended to accept the missionaries' teaching at face value ${ }^{2}$. For Donskoi and especially Kamenskii this disrespectful attitude towards Orthodoxy was another manifestation of the detrimental influence of American society where a poorly educated Creole was exposed to a variety of religious denominations ("sects" in the Orthodox terminology) and even blatant atheism. Excessive American freedom, once again, led to confusion and immorality. In Fr. Anatolii's words, "The Creoles are influenced by the local environment, characterized by the existence of

ioners tried to obtain information about some valuable religious items removed from their cathedral by a clergyman and sent to San Francisco. While they identified with those icons and crosses and considered them part of their community's heritage, the Church felt that it could do with them as it pleased. The parishioners lost but the struggle left a division within the parish and a bitter aftertaste (ARCA, n.d. - e).

${ }^{1}$ In addition, several local schoolteachers, who had recently come from Russia, were accused by the clergy of being "free thinkers."

${ }^{2}$ Comparing his Creole parishioners with the Tlingit ones, Fr. Donskoi wrote, "At least a Tlingit church member would never question the existence of God and especially refuse to let the priest in his home during on church feast days, as a few younger 'Russians' are beginning to do" (ARCA, n.d. - d). 
many sects and the absence of [true] faith in God. They, especially the younger generation, suffer from a lack of principles and moral weakness" (Kamenskii, 1897b).

\section{SERGEI KOSTROMITINOV - A PERFECT SYMBOL OF SITKA'S RUSSIAN AND ORTHODOX HERITAGE}

If the majority of the Sitka Creoles were seen by the Russian clergy as a "miserable remnant" of a former colonial population, who among their parishioners deserved the honor of being characterized as true Russians? The number of such persons was relatively small but membership in the group, which received praise by one clergyman after another, was fairly consistent.

Given the negative characteristics attributed to the majority of the Creoles by the Russian clergy, which I have already described, it is not difficult to predict which qualities a priest like Donskoi or Kamenskii would seek in a parish member he would describe as a "true heir to Sitka's heroic Russian past". Such individuals had to be staunchly Orthodox, fluent as well as literate in Russian and be Russian patriots. They also had to lead a moral life and thus be respected by both the local Creole and the American communities. They were expected to be involved in the Orthodox Brotherhood and give generous donations to the cathedral. It helped if their family could trace its roots to the known employees of the RAC, although later arrivals from Russia could also be counted among the exemplary St. Michael's parish members. Their "race" did not seem to be an issue, although it would have been difficult to celebrate a pure-blooded Alaska Native, and especially a recent convert to Orthodoxy, as a "true heir to the glorious workers of the RAC', while a Creole, who had a Russian last name, whose family had long been associated with the RAC, and whose phenotypical characteristics were somewhat more Slavic than Native, could.

Social class was also important, although since there were only a few well-to-do "Russian" families in Sitka, a well-respected carpenter or a tailor would do almost as well as a merchant. The problem with class was that a number of dedicated Orthodox Church members were Creole women married to American men. Some of these men did convert to Orthodoxy but some did not. Most of these women raised their children Orthodox and remained loyal to the Church. As the wives of successful businessmen and tradesmen, they had the means to contribute regularly to the impoverished local church. The church was grateful to them but could not fully showcase them as the paragons of "old Alaskan Russian families". 
Among such influential Creole families with ties throughout former Russian America (and especially among the Kodiak area Alutiiq people) were the Kashevaroffs who had played a prominent role in the history of the RAC as its workers (navigators, clergymen, etc.). Several of the Kashevaroff men lived in Sitka and included clergymen as well as manual workers. The female members of the family were active as St. Nicholas Brotherhood members. Another respected member of the Russian-Creole community was a Russian-born carpenter Vasilii Shergin (who arrived in Sitka after 1867), famous for his skilled repair work on several Orthodox Alaska churches in southeastern Alaska as we as a true masterpiece - a carved miniature model of the St. Michael's Cathedral that he made for the Alaska Pacific Exhibition of 1909. Over the years he served as both one of the cathedral's trustees and one of the head officers of the Brotherhood (ARCA, n.d. - f).

The man whose name was cited most often in the reports of the Sitka clergy, the travel journals of the Alaska bishop, and the articles in the Russian Orthodox American Messenger (the national newspaper of the Russian Orthodox Church in North America) as that of a "living legend of Alaska Russian heritage" and the "guardian of St. Michael's Cathedral" was Sergei Ionovich Kostromitinov (Kostrometinoff). A brief look at his life and career reveals how he came to represent and symbolize for the Russian-born clergy everything that was lacking in most of his fellow-Creoles ${ }^{1}$.

Sergei Ionovich Kostromitinov (1854-1915), known to the Americans as "George Kostrometinoff," was the son of a Russian merchant who came to Alaska to work for the RAC as one of its general agents. Because of his father's status and especially that of his paternal uncle Peter, who managed Ft. Ross (a former Russian colony in California) and later served as the Russian vice-council in San Francisco, the Kostromitinovs became a wellknown and respected family in Russian America. Like many single Russian men employed by the RAC, Iona Kostromitinov married an Alaska-born woman, Anna Milovidov (Melovidoff), a Creole who was culturally Russian, having been raised in Sitka by the wife of the colony's Governor Etholen. Having lost her husband in an accident prior to the sale of Alaska, the widow Kostromitinov (who had three young children) decided to remain in the land of maternal ancestors.

Born in 1854, Sergei studied at the Russian colonial school (uchilishche) and after 1867 at an American public school. In addition to being fluent in both Russian and English, he also spoke good Tlingit and had some command of one or several other Alaska Native languages. That skill came in very handy when Alaska's new masters began looking for

\footnotetext{
${ }^{1}$ Sergei Kostromitinov's life and career are discussed in detail in Sergei Kan (2013b).
} 
reliable multilingual interpreters who could not only translate from the languages of the colonized to those of the colonizers, but could also serve as the intermediaries or cultural mediators between the latter and the new territory's various inhabitants, from the Sitka Creoles to the local Tlingit to the far away Unangan, Alutiiq and Yup'ik. Being one of the first Sitka Creoles to acquire American citizenship, Sergei developed close relationship with the officials in Sitka. In the early 1880s this intelligent young man was already involved in delivering the votes of the Sitka Creoles to the local American politicians (ARCA, n.d. - e).

Kostrometinoff's exemplary twenty-year-long service as the official interpreter for court and civil officials in Sitka and as the local Deputy US Marshal, as well as his eventual appointment as a colonel in the Territorial Guard illustrate how well he was trusted by Alaska's new authorities. The local American establishment also appreciated Colonel Kostrometinoff's extensive knowledge of the history of Russian America, which was gradually becoming a subject of interest, at least among the local educated class and the government officials. Not surprisingly he consulted the local newspaper on such subjects as the history of the RAC and the meaning of the Orthodox religious observances and was one of the founders of the Alaska Society of Natural History and Ethnology. Sergei was also a successful businessman: he and his younger brother owned a general store in town as well as some land, and in the 1900s he served for a time as the president of Sitka's Chamber of Commerce; he was even a member of the "Arctic Brotherhood", a "white men only" society of Alaska pioneers. It is interesting that while the local Euro-Americans viewed Colonel Kostrometinoff as a "representative of the ancient regime", "a member of one of the best and most favorably known of the Russian families now living in Alaska" (The Alaskan, 1893, p. 1; Alaska-Yukon Magazine, 1908, pp. 147-148) and "one of the very few Caucasian residents of Sitka who bears the distinction of calling that beautiful little city [Sitka] his birthplace", they also saw him as a "pretty thoroughly Americanized" gentleman (Alaska-Yukon Magazine, 1908, pp. 147-148).

Kostrometinoff's public image had to be carefully constructed and maintained. Thus, nowhere in the American press or the government documents pertaining to his life and career was his Creole ancestry ever mentioned ${ }^{1}$. In fact, his mother's obituary incorrectly stated that she had been born in Russia (The Ketchikan Miner, 1907, p. 1). Since he was married to a member of a prominent Creole family, his wife's Creole roots could not

\footnotetext{
${ }^{1}$ A local Russian diarist claimed that in his younger days Kostromitinov even had a Tlingit mistress (a member of the Russian Church), with whom he fathered two children, and that his mother eventually helped "marry her off" to an Orthodox Tlingit man (ARCA, n.d. - e).
} 
be suppressed, but at the time of their wedding (1886), the local newspapers generously described her as a beautiful bride and a member of one of the most respected Alaska Creole families (Alaska State Archives, n.d.).

The Russian clergy undoubtedly knew that Sergei's mother was a Creole but out of respect for one of Sitka's wealthiest Orthodox men, from early on it began listing him in its records as a "United States Citizen, Sergei Ionovich Kostromitinov". It could hardly afford to do otherwise, since for twenty years Sergei Ionovich served as the cathedral's warden (starosta) who made sure that the historic building was kept in a decent shape and donated a good deal of money to it. The local priests and the visiting bishops praised his generosity and emphasized that he was one of the few Alaska church wardens who labored for Orthodoxy and not for money. Of course, in contrast to the poverty-stricken church wardens in the small Alaska villages, Kostrometinoff could afford to serve without any compensation. However, he was not entirely selfless - in return for his labors he gained some prestige, respect and power. In fact, some Russianborn priests and fellow-Creoles complained about his overbearing style of running church affairs and his refusal to share church-related duties with other respected parishioners. However, the Russian-born clergy depended on him as well - he served as an English-Russian and Tlingit-Russian interpreter for them and an intermediary between them and the American authorities. In fact, he managed to remain closely identified with the Orthodox Church without being completely on its side, whenever occasional disputes between the clergy and/or the parishioners and the local U.S. authorities occurred. He also served only as an honorary but not an actual member of the St. Nicholas Brotherhood, thus preferring to be above the fray.

While Kostrometinoff knew when to act as affable "Colonel George" to his Yankee friends, he was a master of welcoming visiting Orthodox dignitaries in true Russian style. He liked to lead the Creole choir in the "Baranov's Song", an old-time favorite of the RAC days, which still brought tears to the eyes of patriotic Russian servants of God (Russian Orthodox American Messener, 1906, vol. 10, p. 447). A visit to Sergei Ionovich's house, where one was met with bread and salt and where Russian zakuski and tea from several samovars awaited the guest, was considered a must for every Orthodox dignitary passing through Sitka (Ziorov, 1893 , p. 53) ${ }^{1}$. One could even find a Russian magazine or a newspaper in this "little corner of Mother Russia".

\footnotetext{
${ }^{1}$ Local American dignitaries and an occasional Yankee visitor of high rank was honored in a similar fashion.
} 
Not surprisingly, Sergei Ionovich was the recipient of several prestigious Russian/Orthodox awards: first an Order of St. Daniel from Prince Nikolai of Montenegro and in 1906 a special silver goblet from the tsar. In his congratulatory speech delivered in St. Michael's Cathedral on the latter occasion, Bishop Innokentii (Pustynskii) praised the "modest, pious, Christian Kostrometinoff family whose name is known far and wide" and then told Sergei Ionovich the following:

The Russian people have a proverb "A prayer to God and a service to the Czar are never lost". It means that the Russian people have a firm faith in God who always hears the prayers of his servants and in due time grants their wishes; and that they also believe in the Orthodox White Czar, an appointed sovereign who rewards every good deed as soon as it comes to his knowledge.

Your reward is given to you for being a guardian of this remarkable monument of the Orthodox faith in this country [i.,e., the St. Michael's cathedral] and it means that your service to the White Russian Czar is never lost" (Russian Orthodox American Messener, 1906, vol. 10, p. 447).

As if to prove the truth of the bishop's words, Sergei Kostrometinoff, who had worn so many different hats in his life, ended it as a priest of the St. Michael's Cathedral. He only got to serve in that capacity for a few years, dying of cancer in 1915; appropriately, he was granted the ultimate honor for an Orthodox person - to be buried underneath the cathedral floor ${ }^{1}$.

\section{CONCLUSION}

Between 1867 and 1917 priests from Russia, who labored in Sitka, tried to use the methods of clerical service and the religious rhetoric acquired back in Russia to deal with an unfamiliar type of parish. Having brought with them the late 19th century ideology of Russian nationalism and monarchism, they found it very difficult to accept that the Russian culture of the local Creoles was in a state of gradual decline, especially among the younger generation. Convinced that their own culture was far superior than any other, and especially the crude new Yankee one, men like Donskoi, Kamenskii and Dashkevich tried to explain this decline by attrib-

\footnotetext{
${ }^{1}$ In 1900, having been offended by some Presbyterian missionaries or government officials with Presbyterian ties, Kostromitinov was seeking a job in Sitka or Seattle involving working for the Russian government or some Russian cause via the intercession of the AK bishop. His interesting letter of May 16, 1900 to the bishop of Alaska mentions it and also some troubles he has had with his American enemies, "With all my heart I thank you for your efforts to direct my future into a Russian stream. It is difficult to get along with one's enemies and so one's spirit [dukh] demands to be reunited with the old, the familiar, with the eternally precious. ... All my sympathies are Russian" (Kostromitinov, 1900).
} 
uting it to a variety of causes, most of them ideological. Not surprising, America became the main culprit.

Of course, they did blame the Creoles themselves for the sorry state of affairs as well. On many occasions the priests emphasized in their writings that very few true Russians remained in Alaska after 1867 (i.e., indicating that the Creoles were only partially Russian) and for decades they insisted on listing most of their parishioners under the rubric of "Creoles". It does not appear that they saw the latter as being racially (biologically) inferior to the Russians, although at least Fr. Anatolii, who dabbled in ethnographic writing, did on occasion use biological reasoning to explain Alaska Natives' sociocultural inferiority compared to the whites (Kamenskii, 1985).

In their efforts to stem the tide of Americanization, the Orthodox priests worked hard to promote Russian education among the young Creoles and actually made some modest progress in that area. Thus, in the early 1900s Sitka had a fairly active Orthodox parish school as well as a small Seminary. Yet here too, conservative nationalist ideology clashed with common sense. For example, Fr. Anatolii fought with a more progressive Russian-born teacher who argued that teaching arithmetic to Creole children in Russian made absolutely no sense. Not surprisingly many of the Creole parents did not see this Russian education as something their children really needed.

Despite their best efforts, the Russian schooling and even the more informal day-to-day Russian culture could not flourish in Sitka without a continuing addition of new immigrants from the mother country. The local Russian-speaking community was simply too small and eventually it disappeared through intermarriage with non-Russians and outmigration. Moreover, conflicts between the Creoles (especially the Alaska born younger ones) and the Russian clergy, had as much to do with fundamental cultural and ideological differences as with issues of personality and leadership style. The two sides were simply beginning to see the role of the priest and his flock in rather different terms.

It appears that even such a staunch nationalist as Kamenskii who, having left Sitka, served in an Orthodox community in Minneapolis before returning to Russia, eventually understood that. A highly educated man, he clearly identified a fundamental difference between the structure of a Russian and an American religious community. In Russia, he argued, the Church was based on a principle of "hierarchical subordination" and was "like a monarchy"; in America, a parish was a democratic community that

\footnotetext{
${ }^{1}$ This practice seems to have ended only in the early-to-mid 1900s, especially under a Creole priest, Fr. Andrei Kashevaroff, who simply divided the entire St. Michael's parish list into "parishioners" (prikhozhane) and "Tlingit". (Parish records — confessional list, ARCA, D 416, Reel 266, 1900-1905).
} 
could hire and fire a priest and could tell him what to do. Although Kamenskii did not advocate surrendering to this Americanism, he did suggest adjusting to it by listening to the leading parishioners, promoting some degree of self-rule in the parish, making compromises with the flock, etc. (Kamenskii, 1908).

When it came to preserving the Russian culture in America, he was more pessimistic and argued that this was more or less a losing proposition. In his Amerkanskie Ocherki, published upon his return to Russia, Fr. Anatolii acknowledged that the preservation of Russian and broader Slavic culture in the United States was very difficult. What could, however, be done, in his view, was the preservation of Orthodoxy.

Of course, neither he nor his colleagues could predict that the dramatic events that took place in Russia a decade later made this task a lot more complicated, but that is another story.

\section{References}

(1906). Russian Orthodox American Messenger, 10, 447.

(1908). Alaska-Yukon Magazine, 4(2), 147-148.

(1911). Russian Orthodox American Messenger, 15, pp. 301-302.

(22 March 1907). The Ketchikan Miner, p. 1.

(6 February 1893). The Alaskan, p. 1.

(7 February 1891). The Alaskan, p. 1.

A Century of Lawmaking for a New Nation: U.S. Congressional Documents and Debates, 1774-1875. (n.d.). Retrieved from https://memory.loc.gov/cgibin/ampage? collId=llsl\&fileName=015/lls1015.db\&recNum $=572$

Afonsky, G. (1977). A History of the Orthodox Church in Alaska (1794-1917). St. Herman's Theological Seminary. Kodiak.

Alaska Russian Church Archives [ARCA] (1900-1905). Parish records - confessional list. D 416, Reel 266.

Alaska Russian Church Archives. (n.d. - a). D 334-D336, Reels 277-279.

Alaska Russian Church Archives. (n.d. - b). D349-D350, Reels 228-229.

Alaska Russian Church Archives. (n.d. - c). D 414, Reel 265.

Alaska Russian Church Archives. (n.d. - d). Donskoi Report to the bishop of Alaska for 1892, 3. D 334, reel 219, 1.

Alaska Russian Church Archives. (n.d. - e). Stepan Ushin's Diary. D 334-D336, Reels 277-279.

Alaska Russian Church Archives. (n.d. - f). Annual Reports, St. Nicholas Brotherhood. D 323, Reel 213. 
Alaska Russian Church Archives. (n.d. - g). Donskoi to Fr. Antonii Dashkevich. D 334, roll 219, 1897, 10.

Alaska Russian Church Archives. (n.d. - h). Minutes of the St. Nicholas Brotherhood. D 323, reel 213, 1895, 74.

Alaska Russian Church Archives. (n.d. - i). St. Nicholas Brotherhood By-laws. D 323, roll 213, 1892,1.

Alaska State Archives. (n.d.). George Kostrometinoff Scrap Book. Juneau.

Cracroft, S., \& DeArmond, R. N. (1981). Lady Franklin Visits Sitka, Alaska 1870: The Journal of Sophia Cracroft, Sir John Franklin's Niece. Alaska Historical Society.

Dashkevich, A. (1898). Alaska Russian Church Archives. Letter to bishop Tikhon Belavin. ARCA, D334, reel 218, 5.

Grinev, A. V. (2011). Social Mobility of the Creoles in Russian America. Alaska History, 26(2), 21-38.

Kamenskii, A. (1897a). Alaska Russian Church Archives. Letter to bishop Nikolai Ziorov. D 335, reel 220, 12.

Kamenskii, A. (1897b). Alaska Russian Church Archives. Report on the Sitka Parish for 1897. ARCA, D 335, reel 220.

Kamenskii, A. (1897c). Alaska Russian Church Archives. Report on the State of the Sitka Diocese. ARCA, D 335, roll 220. 1 .

Kamenskii, A. (1908). American Essays. Odessa. (in Russian).

Kamenskii, A. (1985). Tlingit Indians of Alaska. (S. Kan, Trans.) University of Alaska Press.

Kan, S. (1999). Memory Eternal Tlingit Culture and Russian Orthodox Christianity Through Two Centuries. University of Washington Press.

Kan, S. (2013a). Guest Editor's Introduction: Individuals and Groups of Mixed RussianNative Parentage in Siberia, Russian America, and Alaska. Ethnohistory, 60(3), 351-361. Doi: 10.1215/00141801-2140686.

Kan, S. (2013b). Sergei Ionovich Kostromitinov (1854-1915), or "Colonel George Kostrometinoff": From a Creole Teenager to the Number-One RussianAmerican Citizen of Sitka. Ethnohistory, 60(3), 385-402. Doi: 10.1215/00141801-2140704.

Kan, S. (n.d. - a). Fieldnotes, Sitka, 2000-2018. Manuscript in author's possession.

Kan, S. (n.d. - b). Orthodox Church Brotherhoods of the Sitka Creoles, 1870s-1910s. Alaska History, in print.

Kostromitinov, S. (1900). Alaska Russian Church Archives. Letter to Bishop Tikhon Belavin. ARCA, B 14, reel 16, 1.

Lain, B. D. (1976). The Decline of Russian America's Colonial Society. The Western Historical Quarterly, 7(2), 143-153. Doi: 10.2307/967512. 
Luehrmann, S. (2008). Alutiiq villages under Russian and U.S. Rule. University of Alaska Press.

Metropolitan Clement (Kapalin). (2009). Russian Orthodox Church in Alaska until 1917. Moscow. (in Russian).

Oleksa, M. (1998). Orthodox Alaska: A Theology of Mission. St. Vladimir's Seminary Press.

Parish Records-Confessional List, ARCA. (1870). D 414, Reel 265.

Smith-Peter, S. (2010). Creating a Creole Estate in early nineteenth-century Russian America. Cahiers Du Monde Russe, 51(51/2-3), 441-459. Doi: 10.4000/monderusse.9198.

Smith-Peter, S. (2013). "A Class of People Admitted to the Better Ranks": The First Generation of Creoles in Russian America, 1810s-1820s. Ethnohistory, 60(3), 363-384. Doi: 10.1215/00141801-2140758.

St. Michael Cathedral. (n.d.). Alaska Russian Church Archives. Library of Congress, D 414, Reel 265.

Teichmann, E. (1963). A Journey to Alaska in the Year 1868: Being a Diary of the Late Emil Teichmann. Argosy-Antiquarian.

Vinkovetsky, I. (2011). Russian America an Overseas Colony of a Continental Empire, 1804-1867. Oxford University Press.

Ziorov, N. (1893). From my diary: Vol. 1: Travel notes and experiences while traveling in Alaska and the Aleutian Islands. St. Petersburg. (in Russian).

Znamenski, A. A. (1999). Shamanism and Christianity: Native Encounters with Russian Orthodox Missions in Siberia and Alaska, 1820-1917. Greenwood.

\section{Список литературы}

(1906). Russian Orthodox American Messenger, 10, 447.

(1908). Alaska-Yukon Magazine, 4(2), 147-148.

(1911). Russian Orthodox American Messenger, 15, 301-302.

(22 March 1907 г.). The Ketchikan Miner, p. 1.

(6 February 1893 г.). The Alaskan, p. 1.

(7 February 1891 г.). The Alaskan, p. 1.

A Century of Lawmaking for a New Nation: U.S. Congressional Documents and Debates, 1774 - 1875. (n.d.). Ioann Veniaminoff Notes on the Islands of the Unalashka District. L. Black (Trans.). Retrieved from https://memory.loc.gov/cgibin/ampage?collId=llsl\&fileName $=015 / 11$ s1015.db\&recNum $=572$

Afonsky, G. (1977). A History of the Orthodox Church in Alaska (1794-1917). St. Herman's Theological Seminary. Kodiak.

Alaska Russian Church Archives. (1900-1905). Parish records - confessional list. D 416, Reel 266. 
Alaska Russian Church Archives. (n.d. - a). D 334-D336, Reels 277-279.

Alaska Russian Church Archives. (n.d. - b). D349-D350, Reels 228-229.

Alaska Russian Church Archives. (n.d. - c). D 414, Roll 265.

Alaska Russian Church Archives. (n.d. - d). Donskoi Report to the bishop of Alaska for 1892. D 334, reel 219, 1 .

Alaska Russian Church Archives. (n.d. - e). Stepan Ushin's Diary. D 334-D336, Reels 277-279.

Alaska Russian Church Archives. (n.d. - f). Annual Reports, St. Nicholas Brotherhood. D 323, Reel 213.

Alaska Russian Church Archives. (n.d. - g). Donskoi to Fr. Antonii Dashkevich. D 334, roll 219, 1897, 10.

Alaska Russian Church Archives. (n.d. - h). Minutes of the St. Nicholas Brotherhood. D 323, reel 213, 1895, 74 .

Alaska Russian Church Archives. (n.d. - i). St. Nicholas Brotherhood By-laws. D 323, roll 213, 1892,1.

Alaska State Archives. (n.d.). George Kostrometinoff Scrap Book. Juneau.

Cracroft, S., \& DeArmond, R. N. (1981). Lady Franklin Visits Sitka, Alaska 1870: The Journal of Sophia Cracroft, Sir John Franklin's Niece. Alaska Historical Society.

Dashkevich, A. (1898). Alaska Russian Church Archives. Letter to bishop Tikhon Belavin. ARCA, D334, reel 218, 5.

Grinev, A. V. (2011). Social Mobility of the Creoles in Russian America. Alaska History, 26(2), 21-38.

Kamenskii, A. (1897a). Alaska Russian Church Archives. Letter to bishop Nikolai. D 335 , reel 220, 12 .

Kamenskii, A. (1897b). Alaska Russian Church Archives. Report on the Sitka parish for 1897. ARCA, D 335, reel 220.

Kamenskii, A. (1897c). Alaska Russian Church Archives. Report on the State of the Sitka Diocese. ARCA, D 335, roll 220. 1 .

Kamenskii, A. (1985). Tlingit Indians of Alaska. (S. Kan, Trans.) University of Alaska Press.

Kan, S. (1999). Memory Eternal Tlingit Culture and Russian Orthodox Christianity Through Two Centuries. University of Washington Press.

Kan, S. (2013a). Guest Editor's Introduction: Individuals and Groups of Mixed RussianNative Parentage in Siberia, Russian America, and Alaska. Ethnohistory, 60(3), 351-361. Doi: 10.1215/00141801-2140686.

Kan, S. (2013b). Sergei Ionovich Kostromitinov (1854-1915), or "Colonel George Kostrometinoff": From a Creole Teenager to the Number-One RussianAmerican Citizen of Sitka. Ethnohistory, 60(3), 385-402. Doi:

10.1215/00141801-2140704. 
Kan, S. (n.d. - a). Fieldnotes, Sitka, 2000-2018. Manuscript in author's possession.

Kan, S. (n.d. - b). Orthodox Church Brotherhoods of the Sitka Creoles, 1870s-1910s. Alaska History, in print.

Kostromitinov, S. (1990). Alaska Russian Church Archives. Letter to Bishop Tikhon Belavin. ARCA, B 14, reel 16, 1.

Lain, B. D. (1976). The Decline of Russian America's Colonial Society. The Western Historical Quarterly, 7(2), 143-153. Doi: 10.2307/967512.

Luehrmann, S. (2008). Alutiiq Villages under Russian and U.S. Rule. University of Alaska Press.

Oleksa, M. (1998). Orthodox Alaska: A Theology of Mission. St. Vladimir's Seminary Press.

Parish Records-Confessional List, ARCA. (1870). D 414, Reel 265.

Smith-Peter, S. (2010). Creating a Creole Estate in early nineteenth-century Russian America. Cahiers Du Monde Russe, 51(51/2-3), 441-459. Doi: 10.4000/monderusse.9198.

Smith-Peter, S. (2013). "A Class of People Admitted to the Better Ranks": The First Generation of Creoles in Russian America, 1810s-1820s. Ethnohistory, 60(3), 363-384. Doi: 10.1215/00141801-2140758.

St. Michael Cathedral. (n.d.). Alaska Russian Church Archives. Library of Congress, $D$ 414, Reel 265.

Teichmann, E. (1963). A Journey to Alaska in the Year 1868: Being a Diary of the Late Emil Teichmann. Argosy-Antiquarian.

Vinkovetsky, I. (2011). Russian America an overseas colony of a continental empire, 1804-1867. Oxford University Press.

Znamenski, A. A. (1999). Shamanism and Christianity: Native Encounters with Russian Orthodox Missions in Siberia and Alaska, 1820-1917. Greenwood.

Зиоров, Н. (1893). Из моего дневника: Вып. 1: Путевые заметки и впечатления во время путешествия по Аляске и Алеутским островам. Санкт-Петербург.

Каменский, А. (1908). Американские очерки. Одесса.

Метрополит Клемент (Капалин). (2009). Русская православная церковь на Аляске до 1917 г. Москва. 